\title{
Health and Heritage
}

Srivastava AK*

WISH, India

*Corresponding author: Ambey Kumar Srivastava, WISH, India, Tel: +919314564063; Email: godblessambey@yahoo.com

\section{Opinion}

Volume 2 Issue 5

Received Date: August 28, 2019

Published Date: September 06, 2019

DOI: $10.23880 /$ jqhe- 16000134

\section{Opinion}

Healthy cities create healthy people and it can be vice versa as well. However, the first responsibility should be shouldered by the people who are living in cities is also undeniable. With the decline in environment, slogans like 'Green city Clean city' are popular to create awareness among people. But what has led us to the realization of such slogans? May be because now we are confirmed that if our cities are fine than only we will be fine. Health of human being and health of environment cannot be seen in isolation, as both affect each other. Impact of environment on health is well researched in order to make people more environment friendly and health conscious because changing the human behavior is a preventive health which is cost effective than the curative health. The declining quality in environment of cities still has not been any deterrent to prevent migration of people from rural to urban may be because the necessities like employment, housing, education and better lifestyle scores over the health needs. Moreover, there is also a perception that in cities people have better income prospects so that health needs can be managed to any extent. But we have to think that is this the only way to evolve our cities which are seen as the ultimate destination of millions to fulfill basic needs of a quality life? Talking about cities is nothing new but the way our cities (whether new or old) are gradually becoming vulnerable to unplanned development will lead towards collapse of healthy environment and ultimately the health of city dwellers.

The concept of city is very old. Many cities developed in the past but ruin away with time, whereas many cities still exist. There are cities which are even thousands of years old. Such olden cities which are able to survive are the best evidence of transformation of human settlements, architecture, planning, life style, trade and economy which make cities distinctive from each other. As urbanization is an ongoing phenomenon many more new cities are evolving. It is more relevant for countries like India which has one of the oldest civilizations in the world and which is even though majorly rural but possess tremendous scope for the urbanization. In census 2011 first time after independence the increase in urban population has surpassed the growth of rural population. Rapid pace of urbanization has resulted in more number of urban centers. According to Census 2011, total number of towns has reached to 7,935 after an addition of 2774 towns over the census of 2001. These many urban centers are housing more than 31 per cent of total population of the country. It is projected that by 2039 about half of the India's population will be urban which surely indicates the requirement of more cities.

All cities are not equal in terms of geography, population, infrastructure, amenities and opportunities for better life. That's why there are various classifications of cities mainly based on size of population, size of economy, governance and planning like mega cities, metro cities, million plus cities, municipal corporation, municipalities, small cities, smart cities, tech city, intelligent cities etc. Besides that, cities are also given nick names based on their special quality which is not shared by other. Heritage cities are one such class of cities which carries the legacy of their beautiful past in form of cultural property, both tangible and intangible. Tangible heritage includes buildings and historic places, monuments, artifacts, etc. This different classification of cities is extremely important because they place them in different galaxy of cities. So if new cities are need of the hour to accommodate the rising urban population, what about the cities which symbolizes our heritage?

Heritage is something which connects us with the past, present and future. India is one of the countries which have many olden cities rich in cultural heritage of tangible and intangible form. There are several buildings classified 


\section{Journal of Quality in Health Care \& Economics}

as heritage, but what a big achievement if a whole city area is declared a heritage like happened in case of Jaipur city. Recently big news has made the whole country proud when UNESCO's World Heritage Committee decided to include Jaipur the 'Pink City of India' among World Heritage Sites. There are total 38 sites declared as Heritage in India by UNESCO. Pink city is the latest one to find place in this list but first one is Ahmedabad. The walled city of Jaipur, worldwide famous for its architectural beauty, city planning and vibrant culture, has become the second city of the India to get this accolade. The Observatory (Jantar Mantar) and Amer fort in Jaipur are the two other sites already declared as heritage by UNESCO. So such is the importance of Jaipur city from heritage point of view, which was built in 1727 . This is not a small achievement because it has brought huge responsibility on the people and the urban governance to prove that they can maintain and sustain their heritage against all the urban challenges which the city is experiencing at present. The urban culture of Jaipur city is a fusion of heritage is characterized by the marvelous physical architecture and aesthetic planning and the new emerging trends of urbanization.

Jaipur city is the first well planned city of India and today it is one of the fastest growing mega cities of India with an annual average growth rate higher than the national urban growth rate. It is also true that in 1900, when Jaipur city was largely confined to walled city, its population was just around 160,000. Now it has reached around 3.6 million. Migration is the major factor for the rise in urban population of Jaipur city. The city has increased both in area and its population but walled city has more significance in terms of heritage. About $87 \%$ of the total population lives in the Jaipur Municipal Corporation area, of which just 7\% lives in the walled city, also designated as Central Business District in the Master Plan. The walled city has population around 0.4 million with a spatial extent of 6.7 sq.km. Which is 2.32 percent of the total area of Jaipur Municipal Corporation? The population of walled city has been declined in census 2011 as compared to 2001 due to expansion of city limits and migration of people to outside walled city.

The old walled city has also undergone the phenomenon of urbanization. But to keep our heritage healthy there is a need of healthy urbanization. Unfortunately, the way city is getting urbanized is now doing more harm to the definition of healthy city given by whom because the health determinants are not so healthy. The growing urbanization is also accompanied with several problems like overcrowding, incantation, sewerage, waterlogging, drinking water, crime, encroachment, nutrition, slums, pollution etc. which are not different from many other Indian cities, except in form of severity. They are posing threat to the heritage of the city. WHO in its healthy city concept has emphasized the creation and improvement in physical and social environment as one of the characteristic of healthy city? A healthy physical environment of cities includes clean water bodies, clean air, clean geographical surroundings and safe buildings while social environment is built by the life style of people and healthy interactions with each other. All these features also constitute the health determinants, as indirectly they affect health of the people.

Jaipur is the tenth crowded city in India as per census 2011. The physical and social environment of the city is under stress because of erratic urbanization, shortage of urban basic services, lack of responsible behavior of people towards heritage, poor implementation of rules and regulations, and crisis of funds in urban local bodies to manage and create the resources. Rampant and unplanned urbanization has created a gap between demand and supply of urban basic services, including, housing, water, health, sanitation, education and other urban infrastructure. As per the master plan of Jaipur city, the housing shortage is expected to reach 2, 78,412 (@ household size 5.1) by 2025. Declining land availability and increasing urban population has compelled than 20 percent of population of the city to reside in slum or slum like conditions. Largest number of slum dwellers is living in the limits of Jaipur Municipal Corporation which alone account for 29 percent of slum population of the state. Regrettably, some of traditional castes like Bhat (who make puppets), kalbeliya (famous for snake dance) etc., who are still pursuing their rich traditional occupations and constitute the intangible form of heritage, are residing in slum areas of the city. Presence of slums is aggravating another problem i.e. urban land encroachment.

Encroachment in urban areas like vacant land, near road side, railway lines, around walled city, in markets, etc. is gradually deteriorating the beauty of the city. It is not just restricted to land but also the old traditional water bodies in and around Jaipur city is falling prey to encroachers. The water bodies, on which once the drinking water supply of the whole city depends upon, are being encroached for residential and commercial purpose or for dumping waste of the city. Due to encroachment the historic water bodies are either dried up or their area has been shrunken. Dumping of waste in water bodies, over extraction of ground water and seepage of wastewater from soak pits used in the septic tank system into the 


\section{Journal of Quality in Health Care \& Economics}

ground water has caused the crisis of drinking water in the city because more than 90 per cent of the population of Jaipur city depends on ground water resources for meeting their needs. The chemical examination of water shows poor water quality. The waste disposal system is not efficient enough to keep the city clean. There is no sanitary landfill site for the city. Urban Local Bodies lack any sustainable strategy for door-to-door waste collection system. The problems like water logging, improper drainage, heaps of garbage, stray animals, dirty walls and encroachment on footpath are the evidence of ineffective functioning of urban local bodies. Apart from that, poor monitoring by urban local bodies have allowed people to do illegal construction in walled city area and tampering the original structures and pink color. The projects like Metro rail network has also not only affected the heritage look of the city but have also created the problems related to traffic, road jams, parking and insanitation. Highly congested road, with massive traffic have left little space for easy passage and parking of vehicles. The combined effect of such anomalies in urban governance is that in 2019 the overall ranking of the city in cleanliness survey (Swachhta Survekshan) was $44^{\text {th }}$ among 4237 cities. Poor urban governance has also compelled the High Court to pass strict orders to urban local bodies to preserve the heritage part of the city. The noncompliance of its decision by the urban local bodies has even sometimes forced the court to give deadlines to enforce its orders.

The poor state of health determinants has made health of the city vulnerable and scope for spread of diseases like malaria, dengue, swine flu and chicken guinea. These diseases have become a constant challenge for the health department because every year there are good number of cases reporting from different parts of the city. These diseases are now no more remain seasonal as there are cases even when the weather is not so conducive for breeding. No doubt, the climatic changes are also responsible for this change. Published data shows that the number of dengue cases was reported highest in Jaipur city in recent years. Majority cases of Swine flu in Rajasthan are tested positive from Jaipur in year 2019. There are even many deaths due to dengue and swine flu. In deaths due to Swine flu Rajasthan is the leading state in the country and large number of deaths were reported from Jaipur. Zika virus was also reported from the pink city in year 2018 by the Indian Council of Medical
Research surveillance system in house to house survey in a slum dominated area.

Clean air is also a vital health determinant. The walled city crowded and congested with vehicles is very poor in greenery. There is scarcity of clean air, which is also proved in a survey on air quality by WHO. WHO World Air Quality report 2018, revealed that Jaipur is the most polluted city in Rajasthan and $37^{\text {th }}$ most polluted city in the World among 3000 cities. Unclean air is highly toxic for the health of people. In a study by New York University (NYU) School of Medicine it is proved that even a short stay in a polluted city is damaging to health. It is important in context of tourists who visit the city. Annual report of Rajasthan Tourism department shows that total 1702665 domestic tourists and 633990 foreign tourists visited Jaipur city in 2017. Ignoring the health component of heritage city can be a costly affair because nobody like to lose health.

The urban health challenges cannot be bypassed anymore in heritage cities. Cities are often called as the engines of economic growth and it is very much suitable to heritage cities because of their potential to promote tourism industry which is directly and indirectly linked to many other sectors. The issues and challenges highlighted in this article by taking Jaipur city as an example. But the health aspects of other heritage cities can also be like that or even poor. There is an immediate need to understand the gravity of urban health challenges being faced by all the heritage cities in India because heritage means business in today's world. Health of heritage cities is important for health of economy, health of tourists and health of residents. Even any infrastructure development project need special planning to give health the top priority in the heritage cities. Programs like smart city, intelligent cities etc. should not affect health determinants of the heritage cities. There is a need to link the conservative strategy of the heritage zone of social, scientific, architectural and economic significance with the healthy behavior, healthy planning and healthy implementation to achieve health of the people of heritage cities. We can easily build smart cities but not the heritage cities because it needs hundreds of years. Maintaining the health of heritage cities is important because they are the link of our present with the glorious past and their future is certainly important for all to be known as smart. 